\author{
Joanna GARLIŃSKA-BIELAWSKA \\ Cracow University of Economics \\ garlinsj@uek.krakow.pl
}

\author{
Małgorzata JANICKA \\ University of Lodz \\ malgorzata.janicka@uni.lodz.pl
}

\title{
FRAGILE STATES IN AFRICAN ECONOMIC COMMUNITIES AS EXEMPLIFIED BY THE ECONOMIC AND MONETARY COMMUNITY OF CENTRAL AFRICA (CEMAC) - INVESTMENT ISSUES ${ }^{1}$
}

ABSTRACT The region of Central Africa is abundant in both fragile states and economic communities. According to the theory of international economic integration, in the long term such integration processes should stimulate not only short-term trade effects but also long-term investment effects. The article aims to answer the question whether and how membership of an economic community by a fragile state influences the occurrence of dynamic integration effects. The examination is based on the example of the Economic and Monetary Community of Central Africa (CEMAC). The article uses an analytical and descriptive method on the basis of domestic and foreign literature sources and UNCTAD and IMF statistics. The analysis suggests that from the point of view of member countries of African economic communities, the mere fact of membership of such a community is no vital driver of FDI within the internal market, particularly important to capital-poor fragile states.

The publication was co-financed from a subsidy for maintaining the research capacity of the Faculty of Economics and International Relations at the Cracow University of Economics. 
Key words: Regional Economic Integration, Foreign Direct Investment (FDI), Fragile States/Dysfunctional States

\section{INTRODUCTION}

According to the theory of international economic integration, such integration processes should stimulate not only short-term trade effects but also long-term investment effects. Capital inflow resulting from regional integration is of particular importance to the least developed economies. Africa is the continent with both the highest number of countries characterised by low development levels ${ }^{2}$ and the largest relative (i.e. in relation to the number of states) number of economic communities and integration agreements in the world. Therefore, it is of particular importance to boost capital inflows by economic communities to their member countries.

However, African integration processes differ from those observed in other parts of the world as they are mostly stimulated by external efforts rather than by internal needs. Undoubtedly, an inspiring role was played by the European Community (EC), particularly by one Member State, i.e. France. As early as during the 1957 Treaty of Rome negotiations, France secured its interests, which affected the form of integration in Central Africa, also the formation of the CFA franc-based monetary union, with the currency first pegged to the French franc and then to the euro. Having joined the Communities (1973), the United Kingdom also strengthened its influence in Africa, as reflected in the establishment of the Economic Community of West African States (ECOWAS, 1975), including the previous francophone West African Economic Community (in French: Communauté Economique de l'Afrique de l'Ouest, CEAO) and the former British colonies in West Africa ${ }^{3}$.

Although there are reasons for regional integration in Africa to occur, in most cases the necessary conditions are not met $^{4}$; in addition, the main barrier to attracting capital to the region is the political instability and severe backwardness of most African economies 5 . The European integration model applied to Africa seems to have been rather ineffective in long-term stimulation of economic effects in the communities established. The model was created for politically and economically strong European countries, whereas those

2 In 2018, out of the 47 states classified by the UN as the least developed countries (LDCs) as many as 32 were African countries, List of LDCs, at <http://www.unctad.org>, 22 April 2018.

3 For more, see: M.L. Ropivia, "Failing Institutions and Shattered Space. What Regional Integration in Central Africa?", in: D.C. Bach (ed.), Regionalization in Africa. Integration \& Disintegration, Oxfordd-Indiana 1999, pp. 125-126.

4 For more, see: J. Garlińska-Bielawska, “Międzynarodowa integracja krajów afrykańskich - przeszłość, teraźniejszość, przyszłość”, in: E. Molendowski (ed.), Globalizacja i regionalizacja we wspótczesnym świecie. Ksiega jubileuszowa dedykowana prof. I. Pietrzyk, Kraków 2012, pp. 372-383.

5 For more, see: E. Bombińska, "Bezpośrednie inwestycje zagraniczne krajów rozwijających się na kontynencie afrykańskim”, Finanse, Rynki Finansowe, Ubezpieczenia, no. 3(81) (2016), pp. 26-27. 
in Africa tend to be weak and frequently very fragile ${ }^{6}$. As an example of such a region, Central Africa comprises eight countries ${ }^{7}$; as many as three of them (Chad, the Democratic Republic of the Congo and the Central African Republic) have been ranked high among fragile or failed states for years ${ }^{8}$. At the same time, the states in question are member countries of the economic communities existing in the region, with a long history and ambitious goals. Chad, the Central African Republic and the Democratic Republic of the Congo are member states of two, three and as many as four communities respectively? Therefore, the question is whether and how membership of an economic community by a fragile state influences the occurrence of dynamic integration effects.

Due to the size of the study, the focus is solely on investment issues. The article uses an analytical and descriptive method on the basis of domestic and foreign literature sources and UNCTAD and IMF statistics.

\section{INVESTMENT EFFECTS IN THE THEORY OF INTERNATIONAL ECONOMIC INTEGRATION}

The main economic goal of the creation of international economic communities is to intensify the partners' economic growth and development by boosting trade and stimulating investment in the integrated area. An economic community of any form aims to eliminate tariffs within the community, which leads to a greater market size. It offers enterprises an opportunity to increase economies of scale, simultaneously - owing to more fierce competition - forcing businesses to implement efficiency-oriented measures (cutting production costs, improving quality, faster uptake of technological progress, etc.). Furthermore, increased competition within the community adversely affects the previously dominant position of undertakings in individual markets, forces business combinations, at times making operators collapse. It is of particular importance to small economies where the size of the domestic market limits growth in economic efficiency ${ }^{10}$. In communities characterised by deeper integration, such effects

6 For more on the political and legal classifications of fragile or failed states, see: R. Kłosowicz, Konteksty dysfunkcyjności państw Afryki Subsaharyjskiej, Kraków 2017, pp. 71-106.; H. Dudkiewicz, "Prawo międzynarodowe w kwestii państwa upadłego”, in: R. Kłosowicz, A. Mania (eds.), Problem upadku państw w stosunkach międzynarodowych, Kraków 2012, pp. 67-86.

7 Those are as follows: Cameroon, Gabon, Congo, the Central African Republic, Chad, Equatorial Guinea, the Democratic Republic of the Congo and the Democratic Republic of São Tomé and Príncipe.

$8 \quad$ R. Kłosowicz, Konteksty dysfunkcyjności..., pp. 120-122.

9 Those are as follows: the Common Market for Eastern and Southern Africa, COMESA; the Economic Community of Central African States, ECCAS; the Economic Community of Great Lakes Countries, CEPGL; the Southern African Development Community, SADC. As regards the last community, the Democratic Republic of the Congo is not bound by any trade agreement with the other member countries.

10 K. Żołądkiewicz, "Regionalizacja i regionalizm w gospodarce światowej”, in: R. Orłowska, K. Żołądkiewicz (eds.), Globalizacja i regionalizacja w gospodarce światowej, Warszawa 2012, pp. 186-187. 
may be strengthened by free movement of services and factors of production within the integrated area.

Classical investment effects rank among dynamic (long-term) effects of international economic integration. Those are investment creation and diversion (reversal) effects ${ }^{11}$. In contrast to short-term trade effects, with trade creation as the primary effect, favourable in terms of global welfare, whereas diversion is regarded as disadvantageous (although - from the point of view of the least developed countries in a community it may be desirable $)^{12}$, such an approach is not appropriate in the case of long-term investment effects. The investment creation effect means an increase in total investment in the world economy as a consequence of the establishment of an economic community, whereas the investment diversion effect implies the relocation of investment from third countries to the member countries of the community concerned ${ }^{13}$. But their economic interpretation is not unambiguous. Investment diversion may be a positive phenomenon and involve more efficient use of capital where its marginal productivity is higher, resulting in greater combined income of the member countries (which does not exclude losses suffered by owners of product factors in third countries experiencing disinvestment). Investment creation entails GDP growth, provided that potential savings exceed investment opportunities or if a higher propensity to save can be induced and maintained. Otherwise, investment creation leads to losses as it contributes to recession ${ }^{14}$.

It is also worth emphasising that the investment diversion effect results from the trade creation effect or, basically, from its production sub-effect, i.e. the diversion of supply sources from relatively more expensive domestic suppliers to cheaper partners. The relocation of production to other countries modifies the initial trade effects of the establishment of the economic community concerned. As in the case of the investment creation effect, with regard to the investment diversion effect such changes can also strengthen or weaken the trade creation effect ${ }^{15}$.

Foreign direct investment (FDI) is of particular importance to the development and integration of least developed countries. Inward FDI involves no debt relationships and allows protecting domestic savings. In comparison with other options of the acquisition of capital by a capital-poor region, it has a qualitative advantage. As a result, attracting FDI is regarded as one of the economic priorities of the countries engaged in an economic community ${ }^{16}$. The advantages of direct capital inflow include growth in production capacity and job creation in the host country, technology

11 F. Machlup, Integracja gospodarcza - narodziny i rozwój idei, Warszawa 1986, p. 163.

12 Z. Dobosiewicz, Kraje rozwijające się we wspótczesnej gospodarce światowej, Warszawa 1976, p. 226.

13 J. Misala, Wspótczesne teorie wymiany międzynarodowej i zagranicznej polityki ekonomicznej, Warszawa 2001, p. 359.

14 F. Machlup, Integracja..., pp. 164-165.

15 For more see: M. Niemiec, "Nowe trendy i formy handlu międzynarodowego", in: J. Rymarczyk, M. Niemiec (eds.), Wspótczesne tendencje w handlu międzynarodowym, Wrocław 2007, pp. 306-310.

16 A. Zorska, Korporacje transnarodowe, przemiany, oddziatywania, wyzwania, Warszawa 2007, p. 38. 
and knowledge transfer enhancing overall efficiency ${ }^{17}$. Various mechanisms of the impacts of regional economic integration on FDI flows have been developed, as presented in Table 1.

Table 1. Mechanisms of the impacts of regional economic integration on FDI

\begin{tabular}{|c|c|c|}
\hline Mechanisms & $\begin{array}{l}\text { Effects on intra-regional } \\
\text { FDI flows }\end{array}$ & $\begin{array}{l}\text { Effects on FDI inflows } \\
\text { from outside the region }\end{array}$ \\
\hline $\begin{array}{l}\text { Investment liberalisation and/or } \\
\text { protection provisions in regional } \\
\text { agreements }\end{array}$ & $\begin{array}{l}\text { Enables/encourages increased } \\
\text { flows from regional investors } \\
\text { per se, including existing } \\
\text { third-country investors from } \\
\text { outside the region }\end{array}$ & $\begin{array}{l}\text { Enables/encourages increased } \\
\text { flows from third-country } \\
\text { investors not currently establi- } \\
\text { shed inside the region }\end{array}$ \\
\hline $\begin{array}{l}\text { Trade and market integration } \\
\text { provisions in regional agreements }\end{array}$ & $\begin{array}{l}\text { Enables the reorganisation of } \\
\text { production at the regional le- } \\
\text { vel, including investments and } \\
\text { divestments }\end{array}$ & $\begin{array}{l}\text { Attracts new third-country } \\
\text { investment through enlarged } \\
\text { markets, including within glo- } \\
\text { bal value chains }\end{array}$ \\
\hline $\begin{array}{l}\text { Policy harmonisation implicit in } \\
\text { the implementation of regional } \\
\text { agreements }\end{array}$ & $\begin{array}{l}\text { Encourages investment thro- } \\
\text { ugh reductions in transaction } \\
\text { costs and perceived risk }\end{array}$ & $\begin{array}{l}\text { Enables/encourages increased } \\
\text { inflows if harmonisation en- } \\
\text { compasses investment regula- } \\
\text { tions applicable to third-co- } \\
\text { untry investors }\end{array}$ \\
\hline $\begin{array}{l}\text { Broader pan-regional investment } \\
\text { projects (e.g. infrastructure or } \\
\text { research and development) made } \\
\text { possible by, or integral to, regional } \\
\text { agreements }\end{array}$ & $\begin{array}{l}\text { Provides increased investment } \\
\text { opportunities }\end{array}$ & $\begin{array}{l}\text { Provides increased investment } \\
\text { opportunities }\end{array}$ \\
\hline
\end{tabular}

Source: Regional integration and foreign direct investment in developing and transition economics, UNCTAD (2013), p. 4, at <www.unctad.org>, 21 July 2018.

The creation of economic communities influences both intra-regional flows of FDI and capital inflows from outside the region concerned. Even the mechanism of trade liberalisation and market integration in an integrated area facilitates business activities for existing enterprises (the so-called insiders), at the same time attracting firms from outside the region (the so-called outsiders). The inclusion in regional agreements of investment liberalisation and/or protection provisions creates conditions for increasing capital flows, whereas broad (including investment regulations for both regional and external investors) policy harmonisation in the implementation of agreements allows risk reduction, thus encouraging investments. At times, regional agreements also facilitate or even include the implementation of broader investment projects, which provides new investment opportunities.

17 E. Czarny, J. Menkes, “Napływ kapitału bezpośredniego do krajów rozwijających się - wybrane zagadnienia ekonomiczne i prawne”, Bank i Kredyt, August-September (2007), pp. 66-67. 


\section{REGIONAL ECONOMIC INTEGRATION PROCESSES IN CENTRAL AFRICA}

Regional integration in Central Africa has a long history, dating back to the colonial period; the existing Economic and Monetary Community of Central Africa (also referred to as the Central African Economic and Monetary Community, in French: Communauté Economique et Monétaire de l'Afrique Centrale, abbreviated as CEMAC) is one of the oldest regional communities in Africa. It was created from the Central African Customs and Economic Union (in French: Union Douaniere et Economique de l'Afrique Centrale, UDEAC), which in turn had replaced the Equatorial Customs Union (in French: Union Douaniere Equatoriale, UDE), composed of the following: Gabon, Congo (Brazzaville), the Central African Republic and Chad, i.e. the countries included in the former French Equatorial Africa (in French: Afrique Equatoriale Française, $\mathrm{AEF})^{18}$.

The Central African Customs and Economic Union was established under the Treaty of Brazzaville (Congo) in 1964, for the purpose of speeding up the fulfilment of commitments made within the Equatorial Customs Union, i.e. building the common market with the common customs tariff barrier, involving no internal restrictions on goods and capital transfers ${ }^{19}$. UDEAC was created in conditions of full monetary integration of the countries in the region, in contrast to the linear model adopted in the theory of integration where monetary integration is among the last rather than early stages ${ }^{20}$.

18 The member states of the community were as follows: Gabon, Cameroon, Congo, the Central African Republic and Chad, the country to leave the community in 1968 and to return in 1984. In 1983, UDEAC was joined by Equatorial Guinea. For more, see: Z. Dobosiewicz, Integracja gospodarcza krajów rozwijających się, Warszawa 1991, pp. 77-78.

19 Ibidem, p. 77.

20 It concerns two African areas: West Africa and Central Africa. The issuing of currency in the former started as early as 1920. The year 1945 marked the official creation of the CFA franc (the franc of the French colonies of Africa, in French: le franc des Colonies Françaises d'Afrique), pegged to the French franc. In 1958, the franc of the French colonies of Africa was replaced by the franc of the African Financial Community (in French: le franc de la Communauté Financière Africane). At present: Cameroon, the Central African Republic, Congo, Gabon, Equatorial Guinea and Chad in Central Africa use the franc of Financial Cooperation in Central Africa (in French: le franc de la Coopération Financière en Afrique Centrale, XAF), issued by their common Central Bank (BEAC). In contrast: Benin, Burkina-Faso, Côte d'Ivoire, Guinea-Bissau, Mali, Niger, Senegal and Togo use the franc of the African Financial Community (in French: le franc de la Communauté Financière en Afrique, XOF), issued by the Central Bank of West Africa (in French: Banque Centrale des États de l'Afrique de l'Ouest, BCEAO). The movement of capital within the sub-areas and between either sub-area and France is basically free but each of the two CFA francs is only used within its own area and transfers between the areas are made exclusively through banks. The functioning of the CFA franc areas raises much controversy among scholars; for more see: E. Chrabonszczewska, Strefa franka francuskiego, Warszawa 1989, pp. 8-76; P. Młodkowski, Pozaeuropejskie unie monetarne. Historia i funkcjonowanie, Warszawa 2007, pp. 71-75; B. Ndiaye, “ Przestrzeń i granice monetarne we współczesnej Afryce. Na przykładzie franka CFA”, Forum Politologiczne, vol. 10 (2010), pp. 125-142; K. Mitręga-Niestrój, “ Funkcjonowanie 
Despite a long integration tradition, certain endowments of the member countries with natural resources (including crude oil) and a somewhat facilitated starting point, the process of regional economic integration within UDEAC has been very slow. On the one hand, all the members of the community are natural neighbours; however, two of the countries are landlocked (Chad, the Central African Republic), which makes them dependent on their partners, whereas the whole territory of the community (comparable to the size of India) is characterised by significant latitudinal extension. It involves the existence of several vegetation and climatic zones, also the world's second largest tropical forest, the only one outside the Amazon basin (including part of the territory of Democratic Republic of the Congo). Those are areas which are very difficult to cross and to carry goods, considering underdeveloped networks of roads and navigable waterways. Such difficult climate and transport conditions are accompanied by the incidence of a number of tropical diseases such as malaria.

In the late 1970s, experts from the United Nations Economic Commission for Africa (ECA) developed a concept of creating a new community to cover the whole of Central Africa, supported by Cameroon and Congo, interested the expanding their outlets to include the then Zaire, not very industrialised. The concept was implemented under the Treaty of Libreville (Gabon) in 1983. The new community named the Economic Community of Central African States (ECCAS, in French: Communauté Economique des Etats de l'Afrique Centrale, CEEAC), in addition to the UDEAC member countries (Chad, Cameroon, Congo, Gabon, Equatorial Guinea, the Central African Republic), was joined by Zaire (today's Democratic Republic of the Congo, DR Congo), Burundi, Rwanda and the Democratic Republic of São Tomé and Príncipe ${ }^{21}$.

The concept of creating a new community rather than enlarging the existing one resulted from the difficult economic situation of Zaire, struggling with enormous debt; therefore, not surprisingly, it meant no improvement for the situation in UDEAC. Thus, the low level of intra-regional trade dropped even more, from $4.1 \%$ in 1980 to $2.8 \%$ in $1986 .{ }^{22}$ Burundi, Rwanda and Zaire were then also member countries of the Economic Community of Great Lakes Countries (CEPGL), which created a certain network of overlapping membership in Central Africa. As regards UDEAC, under the Treaty of N'Djamena (Chad) of 1994 it was transformed into the Economic and Monetary Community of Central Africa (in French: Communauté Economique et Monétaire de l'Afrique Centrale, CEMAC). It was initiated by the World Bank, after concluding a reform agreement with the Secretary-General of UDEAC in 1989. France also actively contributed to the project as the country did not wish to give up its traditional area of influence. Initially, the positions of the World Bank and of France differed on one very important issue, namely the devaluation of the CFA franc. As a result, reforms

strefy franka CFA - wstęp do krytycznej analizy", Annales Universitatis Mariae Curie-Sklodowska, sectio H, vol. 51, no. 4 (2017), pp. 247-256.

21 Angola acceded to the community in 1999, whereas Rwanda left in 2007 to return in 2015.

22 R.J. Langhammer, U. Hiemenz, Regional Integration among Developing Countries, Opportunities, Obstacles and Options, Kieler Stundien, vol. 232, Tübingen 1990, p. 84. 
were prepared and adopted on the assumption that there would be no parity change; however, it was changed by as much as $50 \%$ in $1994^{23}$. The reform package also included tax, customs policy, transit and infrastructure reforms, with sectors of strategic importance to the Central African economies (the petroleum and extractive industries) excluded from the reforms. As a result of the reforms, the common external customs tariff was re-introduced with tariffs ranging from $5 \%$ on raw materials to $50 \%$ on luxury products, with preferences to locally produced goods ${ }^{24}$. Consequently, CEMAC is the only customs union in the region notified to the WTO, which means a success on the one hand, but it is not actually reflected in an increased share of intra-regional trade, barely exceeding $2 \%$ in 2015 (Table 1 ).

Table 2. Intra-regional trade of the economic communities in Central Africa (USD million) and the share of intra-regional trade in their total foreign trade (\%) in 1995-2015

\begin{tabular}{|l|c|c|c|c|c|}
\hline Community & $\mathbf{1 9 9 5}$ & $\mathbf{2 0 0 0}$ & $\mathbf{2 0 0 5}$ & $\mathbf{2 0 1 0}$ & $\mathbf{2 0 1 5}$ \\
\hline CEPGL (USD million) & 5 & 4 & 25 & 91 & 222 \\
\hline CEPGL (\%) & 0.3 & 0.4 & 1.0 & 2.4 & 3.3 \\
\hline CEMAC (USD million) & 104 & 96 & 323 & 973 & 591 \\
\hline CEMAC (\%) & 1.8 & 1.1 & 1.4 & 2.7 & 2.2 \\
\hline ECCAS (USD million) & 141 & 152 & 437 & 1.586 & 1,188 \\
\hline ECCAS (\%) & 1.3 & 0.9 & 1.7 & 1.2 & 1.8 \\
\hline
\end{tabular}

Source: Own study based on: UNCTAD Handbook of Statistics 2016, <http://unctad.org/en/PublicationsLibrary/tdstat41_en.pdf>, 22 July 2018.

Internal benefits from trade in Central Africa are mostly based on smuggling, historically embedded in the region. This fact is confirmed by the very low shares of intraregional trade also for CEPGL and ECCAS, 3.3\% and 1.8\% respectively in 2015 (Table 1). In the region, smuggling is an activity both pursued on an enormous scale, i.e. at present usually as 'exports' of coltan from the Democratic Republic of the Congo, mostly used in the manufacture of electronic devices, and well as small-scale informal cross-border trade serving as a livelihood for local population $s^{25}$. Obviously, both forms deprive the states of tax revenues and adversely affect, inter alia, their ability to make obligatory membership contributions to the communities.

The pillars of CEMAC are the customs union UMAC and the economic union UEAC.

UMAC functions properly as it is based on the structure previously established by UDEAC. Its principal institution remains the Bank of Central African States (BEAC),

23 R. Pourtier, "The Renovation of UDEAC. Sense and Nonsense in Central African Integration", in: D.C. Bach (ed.), Regionalization in Africa. Integration and Disintegration, Oxfordd-Indiana 1999, p. 133.

24 Ibid., p. 134.

25 Ibid., pp. 11-14. 
which issues their common currency, the CFA franc, and guarantees its stability by managing monetary policy, exchange operations and reserves in the member countries. The other core element of the Community, the economic union UEAC, is still in the process of formation. In accordance with the CEMAC agreement, a three-step plan was supposed to gradually lead to the establishment of a common market and the setup of the economic union by 2015 but these goals have not been achieved over the years. Very low development levels of the member states, the lack of economic complementarity, disparities between the relatively wealthier countries with access to the sea and the relatively poorer landlocked ones, overlapping powers of many regional institutions, bad infrastructure, the prevalence of diseases and internal rivalry instead of cooperation are the main reasons for the situation.

\section{FOREIGN DIRECT INVESTMENT IN CENTRAL AFRICAN COUNTRIES}

Due to the low economic development levels of certain Sub-Saharan African countries combined with their relative poverty, the key driver for economic growth in those countries becomes direct investment inflow from outside the region rather than direct investment flows within the economic communities. The aforementioned countries lack significant financial surpluses, neither do they have any other advantages attracting FDI - modern products, technology, production organisation methods, etc. Therefore, the inflow of external investment must enhance their investment potential not only financially but also technologically.

Developing countries, especially the least developed economies, experience the phenomenon of the so-called wealth bias. As indicated by M. Clemens, it consists in enterprises from developing countries having very limited access to domestic capital since investors from those countries prefer to invest in foreign markets of developed economies, depriving their national economies even more of those relatively scarce resources of domestic capital. ${ }^{26}$ In such a situation, the marginal productivity of capital, seen by the neo-classical theory as a key determinant of cross-border flows of investment capital, distinctly loses in importance. ${ }^{27}$ In the opinion of M. Clemens, the situation is due not only to the phenomenon of information asymmetry, concerning especially certain developing countries, but also to problems related to the legal environment, e.g. respecting property rights, or underdevelopment of broader infrastructure. As a result, the investment risk greater than in developed economies is not sufficiently compensated for with higher marginal productivity of capital.

26 M.A. Clemens, "Do Rich Countries Invest Less in Poor Countries than the Poor Countries Themselves?”, Center for Global Development, Working Paper, no. 19 (2002), at <http://www.cgdev.org/ content/publications/detail/2771>, 21 September 2018.

27 For more on the subject, see: M. Janicka, Liberalizacja przeptywów kapitatowych w gospodarce światowej. Przypadek Polski, Łódź, 2010, pp. 46-48. 
Table 3. Selected macroeconomic indicators for Sub-Saharan Africa, 2007-2016

\begin{tabular}{|c|c|c|c|c|c|c|c|c|c|c|}
\hline & 2007 & 2008 & 2009 & 2010 & 2011 & 2012 & 2013 & 2014 & 2015 & 2016 \\
\hline GDP (\%) & 7.2 & 6.0 & 3.9 & 7.0 & 5.1 & 4.4 & 5.3 & 5.1 & 3.4 & 1.5 \\
\hline $\begin{array}{l}\text { Investment } \\
\text { (\% of GDP) }\end{array}$ & 21.2 & 21.6 & 22.8 & 21.2 & 20.4 & 21.0 & 21.0 & 22.0 & 21.8 & 19.8 \\
\hline $\begin{array}{l}\text { Gross national } \\
\text { savings } \\
\text { (\% of GDP) }\end{array}$ & 22.6 & 21.8 & 20.4 & 20.7 & 20.1 & 19.5 & 18.7 & 18.3 & 16.1 & 16.1 \\
\hline $\begin{array}{l}\text { Current account } \\
\text { balance } \\
\text { (\% of GDP) }\end{array}$ & 1.5 & 0.2 & -2.4 & -0.8 & -0.6 & -1.7 & -2.2 & -3.8 & -6.0 & -4.1 \\
\hline Inflation (\%) & 7.6 & 13.4 & 9.1 & 7.7 & 10.0 & 8.2 & 6.1 & 6.1 & 8.2 & 12.5 \\
\hline $\begin{array}{l}\text { Volume of } \\
\text { imports of } \\
\text { goods (\%) }\end{array}$ & 17.0 & 12.1 & -6.2 & 11.6 & 11.9 & 5.3 & 5.4 & 5.9 & 4.6 & -7.5 \\
\hline $\begin{array}{l}\text { Volume of } \\
\text { exports of } \\
\text { goods (\%) }\end{array}$ & 7.7 & 2.3 & -5.1 & 7.1 & 0.5 & 1.3 & 4.5 & -0.2 & 3.0 & -1.6 \\
\hline
\end{tabular}

Source: IMF, World Economic Outlook Database, April 2018, at <www.imf.org>, 22 August 2018

The data contained in Table 3 concerns the whole of Sub-Saharan Africa (a total of 45 states), also comprising countries such as Nigeria or the Republic of South Africa. Notably, the region was evidently affected by the global crisis of 2008 onwards, as illustrated by the deterioration of some of the indicators in question after the crisis; in particular, it must be pointed out that there was a relative decline in national savings with similar investment levels maintained. It means that the shortage of investment funds needed to be acquired in foreign markets (as reflected in the current account balance). Simultaneously, the fall in national savings/GDP, particularly in 2015, contributed to a decrease in investment/GDP in 2016, which reduced the current account deficit. In addition, it is worth stressing that the Sub-Saharan African countries experienced relatively minor slowdown of GDP (in each of the years covered, the growth rate was positive), a favourable phenomenon against the backdrop of the world economy.

A good starting point for the analysis of FDI flows in the member countries of CEMAC (including, as mentioned above, Chad, the Democratic Republic of the Congo and the Central African Republic) is a closer look at the investment climate in the area (see Table 4). As indicated by A. Akame, M. E. Ekwelle and G.N. Njei, the values of indices defining the investment climate for CEMAC are far from satisfactory - below 50 points (out a maximum of 100). ${ }^{28}$

28 A. Akame, M.E. Ekwelle, G.N. Njei, The Impact of Business Climate on Foreign Direct Investment in the CEMAC Region, Journal of Economics and Sustainable Development, vol. 7, no. 22 (2016), p. 67. 
Table 4. Business Climate Indices for the CEMAC region, 2007-2014

\begin{tabular}{|c|c|c|c|c|}
\hline Year & $\begin{array}{c}\text { Doing Business } \\
\text { Index (DBI) }\end{array}$ & $\begin{array}{c}\text { Economic } \\
\text { Freedom Index } \\
(\mathbf{E F I})\end{array}$ & $\begin{array}{c}\text { Corruption } \\
\text { Perception } \\
\text { Index (CPI) }\end{array}$ & $\begin{array}{c}\text { Ibrahim Index } \\
\text { of African } \\
\text { Governance } \\
\text { (IIAG) }\end{array}$ \\
\hline 2007 & 35.9 & 52.2 & 22.5 & 50.8 \\
\hline 2008 & 36.2 & 49.2 & 49.8 & 49.8 \\
\hline 2009 & 38.6 & 49.5 & 39.7 & 39.7 \\
\hline 2010 & 38.5 & 49.0 & 40.1 & 40.1 \\
\hline 2011 & 41.8 & 48.3 & 41.8 & 41.8 \\
\hline 2013 & 42.0 & 48.6 & 41.6 & 41.6 \\
\hline 2014 & 44.1 & 48.2 & 39.6 & 39.6 \\
\hline
\end{tabular}

Note: 0 for the worst score, 100 for the best score.

Source: A. Akame, M. E. Ekwelle, G. N. Njei, The Impact of Business Climate on Foreign Direct Investment in the CEMAC Region, Journal of Economics and Sustainable Development, Vol. 7, No. 22, 2016, p. 67, <www.iiste.org >, 22 August 2018.

Although the value of the most popular index of the World Bank, the Doing Business Index, was on the rise and the CPI showed distinct improvement after 2007, in the group of the Sub-Saharan African countries the members of CEMAC rank very low in the World Bank's Doing Business ranking (last but three, four and five respectively among the 45 countries covered ${ }^{29}$. In such a situation, it is difficult to positively assess the investment climate in CEMAC.

Table 5. FDI stock, by region and economy, 2000, 2010, 2017 (USD million)

\begin{tabular}{|l|c|c|c|c|c|c|}
\hline \multirow{2}{*}{ Region/economy } & \multicolumn{3}{|c|}{ FDI inward stock } & \multicolumn{3}{c|}{ FDI outward stock } \\
\hline World & 2000 & 2010 & 2017 & 2000 & 2010 & 2017 \\
\hline $\begin{array}{l}\text { Developing } \\
\text { economies }\end{array}$ & $7,380,453$ & $20,279,391$ & $31,524,356$ & $7,409,630$ & $20,981,762$ & $30,837,927$ \\
\hline Africa & $1,546,082$ & $6,123,095$ & $10,353,481$ & 690,731 & $3,059,932$ & $6,898,384$ \\
\hline Central Africa* & 152,801 & 598,291 & 866,817 & 39,884 & 134,348 & 365,619 \\
\hline CEMAC & 5,053 & 39,228 & 87,819 & 1,720 & 2,363 & 3,674 \\
\hline Cameroon & $3,274^{* *}$ & 29,272 & 58,295 & $1,679 * * *$ & 2,262 & 3,535 \\
\hline
\end{tabular}

“Doing Business 2018. Reforming to Create Jobs", Region Profile of Sub-Saharan Africa (SSA), World Bank Group, p. 4, at <http://www.doingbusiness.org/reports/regional-reports>, 22 September 2018. 


\begin{tabular}{|l|c|c|c|c|c|c|}
\hline \multirow{2}{*}{ Region/economy } & \multicolumn{3}{|c|}{ FDI inward stock } & \multicolumn{3}{c|}{ FDI outward stock } \\
\cline { 1 - 5 } & 2000 & 2010 & 2017 & 2000 & 2010 & 2017 \\
\hline $\begin{array}{l}\text { Central African } \\
\text { Republic }\end{array}$ & 104 & 511 & 651 & 43 & 43 & 43 \\
\hline Chad & 576 & 3,594 & 5,439 & 70 & 70 & 70 \\
\hline $\begin{array}{l}\text { Democratic Republic } \\
\text { of the Congo }\end{array}$ & 617 & 9,368 & 22,527 & 34 & 229 & 2,557 \\
\hline Equatorial Guinea & 1,060 & 9,413 & 13,715 & - & 3 & 3 \\
\hline Gabon & - & 3,287 & 9,489 & 280 & 946 & 175 \\
\hline
\end{tabular}

Notes: ${ }^{*}$ CEMAC plus Burundi, Congo, Rwanda, São Tomé and Príncipe; ${ }^{* *}$ without Gabon; ${ }^{* * *}$ without Equatorial Guinea.

Source: own study based on the World Investment Report 2018, pp. 188-189.

Table 6. FDI stock, by region and economy, 2000, 2010, 2017 (\%)

\begin{tabular}{|c|c|c|c|c|c|c|}
\hline \multirow{2}{*}{ Region/economy } & \multicolumn{3}{|c|}{ FDI inward stock } & \multicolumn{3}{|c|}{ FDI outward stock } \\
\hline & 2000 & 2010 & 2017 & 2000 & 2010 & 2017 \\
\hline World & 100.0 & 100.0 & 100.0 & 100.0 & 100.0 & 100.0 \\
\hline $\begin{array}{l}\text { Developing economies } \\
\text { (share in the World) }\end{array}$ & 20.9 & 30.3 & 32.8 & 9.3 & 14.6 & 22.4 \\
\hline $\begin{array}{l}\text { Africa (share in Developing } \\
\text { Economies) }\end{array}$ & 9.9 & 9.8 & 8.4 & 5.8 & 4.4 & 5.3 \\
\hline Central Africa* (share in Africa) & 3.3 & 6.6 & 10.1 & 4.3 & 1.8 & 1.0 \\
\hline CEMAC (share in Africa) & $2.1^{* *}$ & 4.9 & 6.7 & $4.2^{* * *}$ & 1.7 & 1.0 \\
\hline Cameroon (share in CEMAC) & - & 10.6 & 11.1 & - & 42.9 & 19.4 \\
\hline $\begin{array}{l}\text { Central African Republic } \\
\text { (share in CEMAC) }\end{array}$ & - & 17.5 & 11.2 & - & 1.9 & 1.2 \\
\hline Chad (share in CEMAC) & - & 12.3 & 9.3 & - & 3.1 & 2.0 \\
\hline $\begin{array}{l}\text { Democratic Republic of the Congo } \\
\text { (share in CEMAC) }\end{array}$ & - & 32.0 & 38.6 & - & 10.1 & 72.3 \\
\hline $\begin{array}{l}\text { Equatorial Guinea } \\
\text { (share in CEMAC) }\end{array}$ & - & 32.2 & 23.5 & - & 0.1 & 0.0 \\
\hline Gabon (share in CEMAC) & - & 11.2 & 16.3 & - & 41.8 & 5.0 \\
\hline
\end{tabular}

Note: * CEMAC plus Burundi, Congo, Rwanda, São Tomé and Príncipe; ** without Gabon - no percentage calculation in relation to CEMAC; ${ }^{* * *}$ without Equatorial Guinea - no percentage calculation in relation to CEMAC.

Source: own study based on the data from Table 5

The data contained in Tables 5 and 6 indicates that the stock of FDI in Central African countries, including in the CEMAC member states, was on the rise. However, it 
is worth noting that in 2010-2017 Africa as a whole experienced a fall in FDI stock in relation to the group of developing countries, even though developing countries gained in importance in that respect in the global economy. At the same time, the CEMAC member to absorb the most FDI in absolute terms was the Democratic Republic of the Congo (nearly 40\%); the country was also the main FDI exporter in the community (more than 70\%). In contrast to the upward trend in CEMAC with regard to the stock of inward FDI, the stock of outward FDI was gradually falling ( $1 \%$ in relation to the whole of Africa in 2017, against over $4 \%$ in 2000).

Table 7. FDI inflows, by region and economy, 2012-2017 (USD million)

\begin{tabular}{|l|c|c|c|c|c|c|}
\hline Region/economy & $\mathbf{2 0 1 2}$ & $\mathbf{2 0 1 3}$ & $\mathbf{2 0 1 4}$ & $\mathbf{2 0 1 5}$ & $\mathbf{2 0 1 6}$ & 2017 \\
\hline World & $1,574,712$ & $1,425,377$ & $1,338,532$ & $1,921,306$ & $1,867,533$ & $1,429,807$ \\
\hline Developing economies & 651,500 & 648,539 & 685,292 & 744,032 & 670,158 & 670,658 \\
\hline Africa & 51,985 & 50,790 & 52,440 & 56,633 & 53,190 & 41,772 \\
\hline Central Africa* & 5,461 & 5,428 & 5,306 & 8,305 & 7,345 & 5,733 \\
\hline CEMAC & 5,465 & 4,941 & 3,113 & 4,086 & 3,415 & 4,166 \\
\hline Cameroon & 739 & 567 & 727 & 627 & 664 & 672 \\
\hline Central African Republic & 70 & 2 & 3 & 3 & 7 & 17 \\
\hline Chad & 580 & 520 & -676 & 559 & 244 & 335 \\
\hline $\begin{array}{l}\text { Democratic Republic } \\
\text { of the Congo }\end{array}$ & 3,312 & 2,098 & 1,843 & 1,674 & 1,205 & 1,340 \\
\hline Equatorial Guinea & 985 & 983 & 168 & 233 & 54 & 304 \\
\hline Gabon & -221 & 771 & 1,048 & 990 & 1,241 & 1,498 \\
\hline
\end{tabular}

Note: * CEMAC plus Burundi, Congo, Rwanda, São Tomé and Príncipe.

Source: own study based on the World Investment Report 2018, pp. 184-185.

Table 8. FDI inflows, by region and economy, 2012-2017 (\%)

\begin{tabular}{|c|c|c|c|c|c|c|}
\hline Region/economy & 2012 & 2013 & 2014 & 2015 & 2016 & 2017 \\
\hline World & 100.0 & 100.0 & 100.0 & 100.0 & 100.0 & 100.0 \\
\hline $\begin{array}{l}\text { Developing economies } \\
\text { (share in the World) }\end{array}$ & 41.4 & 45.5 & 51.2 & 38.7 & 35.9 & 46.9 \\
\hline $\begin{array}{l}\text { Africa (share in develo- } \\
\text { ping economies) }\end{array}$ & 8.0 & 7.8 & 7.7 & 7.6 & 7.9 & 6.2 \\
\hline $\begin{array}{l}\text { Central Africa* } \\
\text { (share in Africa) }\end{array}$ & 10.5 & 10.7 & 10.1 & 14.7 & 13.8 & 13.7 \\
\hline $\begin{array}{l}\text { CEMAC (share in } \\
\text { Africa) }\end{array}$ & 10.5 & 9.7 & 5.9 & 7.2 & 6.4 & 10.0 \\
\hline
\end{tabular}

Note: * CEMAC plus Burundi, Congo, Rwanda, São Tomé and Príncipe.

Source: own study based on the World Investment Report 2018, pp. 184-185. 
The data concerning inward FDI confirms the previous conclusions - in 20122017, the country to attract the most FDI in absolute terms was the Democratic Republic of the Congo. It is hardly surprising - the Democratic Republic of the Congo has enormous natural resources, thus the interest from foreign corporations wishing to extract and process them. However, it is seriously doubtful whether such FDI inflows improve the economic situation of the host country, contributing to increased investment capital, job creation, modern technology imports, etc. The Democratic Republic of the Congo ranks among the lowest-income countries in the world - in 2017, GDP per capita was approx. USD $409^{30}$. The most significant challenge currently facing the Democratic Republic of the Congo in the context of international economic relations is to rebuild broader public and private infrastructure, destroyed during the civil war. Membership by the DRC of the economic community CEMAC has not translated into an increased volume of FDI from other member countries. At present, inward FDI mainly comes from the USA, Germany, Belgium, France and the Republic of South Africa $^{31}$. The data contained in Table 7 indicates that participation in CEMAC adds no value to its member countries in terms of inward FDI - there is no unambiguous upward trend in FDI inflows in CEMAC, whereas those are on the rise in the Central African region.

\section{CONCLUSIONS}

To recapitulate, the theory indicates that the creation of economic communities should cause investment effects in the long term. Despite the establishment of a great number of (or even too many) economic communities in Sub-Saharan Africa, the policy pursued in Africa for years, unfavourable to foreign investment, combined with the so-called old regionalism agreements, made inward FDI very minute. In the 2010s, the African continent continued to have unused potential for foreign investors - in 2012-2017, the share of FDI inflows to Africa was barely $7-8 \%$ of inward FDI in developing countries. From the point of view of member countries of African economic communities, the mere fact of membership of such a community is no vital driver of FDI within the internal market, particularly important to capital-poor fragile states. The member countries lack appropriate investment funds or engage in outward investments (the so-called wealth bias), whereas advanced economies invest their capital to make use of specific competitive advantages of individual member states (mostly natural resource endowments), not necessarily taking account of an increased sense of security and stability arising from the creation of the economic community concerned. Therefore, inward FDI in fragile states such as the aforementioned Democratic Republic of the Congo enables the exploitation

30 Congo GDP per capita, Trading Economies, at <https://tradingeconomics.com/congo/gdp-percapita>, 23 September 2018.

31 E. Mahembe, N.M. Odhiambo (2014), "A critical review of FDI inflows and economic growth in low-income SADC countries: prospects and challenges", Problems and Perspectives in Management, vol. 12, no. 1 (2014), p. 9 
of natural resources indispensable to manufacturing in developed countries rather than foster the development of the economic potential of the former.

\section{BIBLIOGRAPHY}

Akame A.J., Ekwelle, Metougue E., Njei, Ndonghandou G., "The Impact of Business Climate on Foreign Direct Investment in the CEMAC Region", Journal of Economics and Sustainable Development, vol. 7, no. 22 (2016).

Bombińska E., "Bezpośrednie inwestycje zagraniczne krajów rozwijających się na kontynencie afrykańskim", Finanse, Rynki Finansowe, Ubezpieczenia, no. 3(81) (2016), at <http:// dx.doi.org/10.18276/frfu.2016.81-03>.

Chrabonszczewska E., Strefa Franka Francuskiego, Warszawa 1989.

Clemens M.A., "Do Rich Countries Invest Less in Poor Countries than the Poor Countries Themselves?", Center for Global Development Working Paper, no. 19, December 2002, at $<$ http://www.cgdev.org/content/publications/detail/2771>.

Czarny E., Menkes J., "Napływ kapitału bezpośredniego do krajów rozwijających się - wybrane zagadnienia ekonomiczne i prawne”, Bank i Kredyt, no. 8-9 (2007).

Dobosiewicz Z., Integracja gospodarcza krajów rozwijających się, Warszawa 1991.

Dobosiewicz, Z., Kraje rozwijające się we wspótczesnej gospodarce światowej, Warszawa 1976.

"Doing Business 2018. Reforming to Create Jobs", Region Profile of Sub-Saharan Africa (SSA), World Bank Group, at <http://www.doingbusiness.org/reports/regional-reports>.

Dudkiewicz H., "Prawo międzynarodowe w kwestii państwa upadłego", in: R. Kłosowicz, A. Mania (eds.), Problem upadku państw w stosunkach międzynarodowych, Kraków 2012.

Garlińska-Bielawska J., "Międzynarodowa integracja krajów afrykańskich - przeszłość, teraźniejszość, przyszłość, in: E. Molendowski (ed.), Globalizacja i regionalizacja we wspótczesnym świecie. Ksiegga jubileuszowa dedykowana prof. I. Pietrzyk, Kraków 2012.

Trading Economics, at <https://tradingeconomics.com/congo/gdp-per-capita> .

Janicka M., Liberalizacja przeptywów kapitatowych w gospodarce światowej. Przypadek Polski, Łódź, 2010.

Kłosowicz R., Konteksty dysfunkcyjności państw Afryki Subsaharyjskiej, Kraków 2017.

Langhammer R.J., Hiemenz U., Regional Integration among Developing Countries, Opportunities, Obstacles and Options, Kieler Studien, vol. 232, Tübingen 1990.

List of LDCs, at <http://www.unctad.org $>$.

Machlup F., Integracja gospodarcza - narodziny i rozwój idei, Warszawa 1986.

Mahembe E., Odhiambo N.M., "A critical review of FDI inflows and economic growth in lowincome SADC countries. Prospects and challenges", Problems and Perspectives in Management, vol. 12, no. 1 (2014).

Misala J., Wspótczesne teorie wymiany międzynarodowej i zagranicznej polityki ekonomicznej, Warszawa 2001.

Mitręga-Niestrój K., "Funkcjonowanie Strefy Franka CFA - wstęp do krytycznej analizy", Annales Universitatis Mariae Curie-Sklodowska. sectio H (Oeconomia), vol. 51, no. 4 (2017), at $<$ http://dx.doi.org/10.17951/h.2017.51.4.247>. 
Młodkowski P., Pozaeuropejskie unie monetarne. Historia i Funkcjonowanie, Warszawa 2007.

Ndiaye B., "Przestrzeń i granice monetarne we współczesnej Afryce. Na przykładzie strefy franka CFA”, Forum Politologiczne, vol. 10 (2010).

Niemiec M., Nowe trendy i formy handlu miedzynarodowego, in: J. Rymarczyk, M. Niemiec (eds.), Wspótczesne tendencje w handlu międzynarodowym, Wrocław 2007.

Pourtier R., "The Renovation of UDEAC. Sense and Nonsense in Central African Integration", in: D.C. Bach (ed.), Regionalisation in Africa. Integration and Disintegration, Oxford-Indiana 1999.

Ropivia M.-L., "Failing Institutions and Shattered Space. What Regional Integration in Central Africa?", in: D.C. Bach (ed.), Regionalisation in Africa. Integration and Disintegration, Oxford-Indiana 1999.

Regional integration and foreign direct investment in developing and transition economics, UNCTAD, at <www.unctad.org $>$.

World Economic Outlook Database, IMF, April 2018, at <www.imf.org>.

Zorska A., Korporacje transnarodowe, przemiany, oddziatywania, wyzwania, Warszawa 2007.

Żołądkiewicz K., Regionalizacja i regionalizm $w$ gospodarce światowej, in: R. Orłowska, K. Żołądkiewicz (eds.), Globalizacja i regionalizacja w gospodarceśsiatowej, Warszawa 2012.

Joanna GARLIŃSKA-BIELAWSKA, Ph.D. - an Assistant Professor in the Department of International Economics at Cracow University of Economics. Her research interests are focused on the economics of international integration (especially between less-developed countries), economic problems of developing countries, regionalization in Africa. She is also a lecturer at Cracow University of Economics - courses in international economics, economics of European integration, regionalization in the world economy. Joanna Garlińska-Bielawska is a member of international research group: Le réseau universitaire des Pays du Grupe du Vysegrad (PGV) and Economic Society of Thessaloniki.

Prof. Małgorzata JANICKA, Ph.D. - an Associate Professor in Economics at the University of Lodz (Poland). She is the Deputy Director of the Institute of International Economics, the Head of the Department of International Finance and Investment and the Head of the Centre for Capital Investment Research at the University of Lodz, Faculty of Economics and Sociology. Her research interest covers International Economics and International Finance (especially International Capital Flows and International Monetary Systems). 